УДК 616.24-002.5-008.811.9-089

DOI 10.11603/2414-4533.2016.4.7188

(c) Ю. Ф. КОШАК

КУТОР “Тернопільський обласний протитуберкульозний диспансер”

\title{
Сучасна діагностика в хірургічному лікуванні легеневого туберкульозу, асоційованого з формою недрібноклітинного раку легень
}

\author{
YU. F. KOSHAK \\ Ternopil Regional Anti-tuberculosis Dispensary
}

\section{MODERN DIAGNOSTICS IN SURGICAL TREATMENT OF PULMONARY TUBERCULOSIS ASSOCIATED WITH NON-SMALL CELL LUNG CANCER}

\begin{abstract}
Сучасні підходи до хірургічного лікування поєднаних форм легеневого туберкульозу та недрібноклітинного раку легень (НДРЛ) - це використання сучасного рентгенологічного обстеження, зокрема поліпозиційної цифрової флюорографії, 3 метою ранньої діагностики та цифрової обробки вогнищево-інфільтративних уражень від об’ємного ракового процесу. Спіральна комп’ютерна томографія органів грудної клітки (СКТ ОГК) з внутрішньовенним контрастним підсиленням дає нові можливості в плані ранньої диференційної діагностики легеневого туберкульозу (ТБ) від ракового процесу, уточнює стадійність за TNM (статусу внутрішньогрудних та медіастинальних лімфовузлів), а також виключає віддалені метастази, що прогностично дозволяє запланувати хірургічне лікування більш радикально, використовуючи той чи інший метод доступу до хірургічної лімфодисекції з видаленням туберкульозного ураження, асоційованого 3 об'ємним утвором.
\end{abstract}

\begin{abstract}
The modern approaches in the surgical treatment of co-existent forms of pulmonary tuberculosis and non-small cell lung cancer (NSCLC) is the use of the modern $x$-ray examination, particular polipositional digital $x$-ray for the early diagnosis and digital processing of cancer lesions. Spiral computer tomography of thorax organs (SCT) with the vennim contrast provides new possibilities in terms of early differential diagnosis between pulmonary tuberculosis (TB) and cancer, clarifies stagging of lung cancer to TNM (tumor,nodus,metastasis) and eliminates remote metastases, that prognosticly allows us to schedule the surgical treatment more radically, using one or another method of access to surgical limfodisection with removal of tuberculosis lesions associated with lung carcinoma.
\end{abstract}

Постановка проблеми і аналіз останніх досліджень та публікацій. В Україні рак легень (РЛ) вийшов на перше місце у структурі онкологічної захворюваності чоловічого населення [1]. За останні 15 років почастішали випадки пізніх рецидивів туберкульозу легень, виникнення мультирезистентних форм ТБ, поєднання ВІЛ-інфекції з вперше діагностованими формами ТБ, виникнення бронхогенного раку у хворих із залишковими туберкульозними змінами в легенях, а також одночасні асоціації НДРЛ та активного ТБ. Низька ефективність своєчасної диференційної діагностики цієї поєднаної патології зумовлює пошук критеріїв розпізнавання вогнищево-інфільтративного ураження легень від об'ємного ракового процесу на ранніх стадіях розвитку [2, 3]. Висока роздільна здатність сучасної СКТ сприяє відтворенню різної щільності тканин відповідно до анатомічних зрізів. Відсутність проекційного ефекту та скіалогічної сумації дає можливість реконструювання зображення у 2D, 3D форматах з використан- ням MIP, Min IP та віртуальної бронхоскопії, дає величезний діагностичний об'єм візуалізації без інвазивного втручання. Контрастне підсилення та його динаміка дозволяють оцінити васкулярність тканин, яка є різною для неопластичного процесу та казеозного некрозу чи гранульоми, а також оцінити відношення процесу до магістральних судин. Пункційна біопсія периферичних змін у легеневій тканині під контролем КТ чи відеоторакоскопії (ВТС) довели високу інформативну здатність у гістологічній верифікації процесу в передопераційному періоді [5]. Діагностика поєднаних форм легеневого туберкульозу та раку завжди складна. У зв’язку з відсутністю специфічної клінічної картини раку легень перші його ознаки можуть бути виявлені лише за допомогою рентгенологічних методів обстеження. Діагностика легеневого раку у хворих, які перенесли туберкульоз легень або мають активний туберкульоз легень, може бути поділена на такі етапи: виявлення, диференційна діагностика і верифікація. У зв'язку з цим променеві 
методи діагностики повинні вирішувати дві проблеми: чутливості для виявлення ранніх проявів РЛ і специфічності для визначення характеру патології. Причому ці завдання повинні адекватно виконуватися на всіх етапах діагностики, від скринінгу до методів дефінітивного дослідження.

Спостереження за хворими 3 перенесеним, неактивним туберкульозом легень в основному відбувається в тубдиспансерах, де динаміка оцінюється на підставі флюорографічного дослідження як основного методу скринінгу. Проблеми останніх років знижують кількість обстежених груп населення, що, у свою чергу, призвело до почастішання ускладнених форм туберкульозу, неоперабельного НДРЛ. Все це істотно знизило діагностику раку та збільшило летальність від поєднаних форм ТБ. Проте флюорографічне дослідження має обмежені діагностичні можливості, його чутливість відносно туберкульозу легень складає $(81,6 \pm 0,6) \%$, а відносно раку легень всього $(37 \pm 0,5) \%$, що зовсім недостатньо [5].

Відеоторакоскопія здатна вирішувати ті ж завдання, що й трансторакальна біопсія, у поєднанні $з$ можливістю лікувальних маніпуляцій та прецизійної біопсії. За літературними даними, тільки відеоторакоскопія здатна швидко і надійно вирішити проблему диференційної діагностики ранніх форм легеневого раку, туберкульом, метастатичної дисемінації з низькою вірогідністю ускладнень і дисемінації МБТ або злоякісних клітин у плевральній порожнині, володіючи перевагами малоінвазивних методик. Проте попередній або супутній туберкульозний процес накладає значні обмеження на можливість відеоторакоскопічної резекції легені: виражені плевральні зрощення в плевральній порожнині в зоні специфічних змін та їх велика протяжність при поширеному туберкульо- зі легень, обсіменіння легеневої тканини з формуванням дрібних вогнищ. Відеоторакоскопія 3 браш-біопсією в діагностиці поширеного РЛ значно перевершує за своїми можливостями цитологічне дослідження плевральної рідини і трансторакальну біопсію плеври. Чутливість останніх двох методик склала 64 і 55 \% для злоякісного плевриту і лише 20 і 18 \% - для туберкульозного відповідно.

Мета роботи: підвищення можливості ранньої діагностики НДРЛ у хворих на туберкульоз легень, уточнення стадійності асоційованих форм та проведення радикального хірургічного лікування з використанням того чи іншого торакального доступу.

Матеріали і методи. У дослідження був включений 91 пацієнт віком від 40 до 65 років за період 2001-2015 рр., у якого НДРЛ поєднувався з активним легеневим туберкульозом. Дане дослідження виконували на базі двох хірургічних відділень: фтизіохірургічного відділення КУТОР “Тернопільський обласний протитуберкульозний диспансер” та легенево-хірургічного відділення К3 “Дніпропетровське обласне комунальне клінічне лікувально-профілактичне об’єднання “ФТИЗІАТРІЯ” ДОР. Попередній відбір хворих проведено з урахуванням вимог до клінічного дослідження за такими критеріями, що базуються на аналізі даних літератури та власному досвіді. Проаналізовано дані СКТ у пацієнтів із вперше виявленим ТБ і НДРЛ, хворих з рецидивами туберкульозу та у хворих із залишковими туберкульозними змінами. Динамічне обстеження на СКТ, ангіографія, віртуальна ендоскопія, пункційна біопсія під контролем КТ (рис. 1) дали можливість диференційної діагностики патологічного процесу з максимальним наближенням до гістологічної верифі-
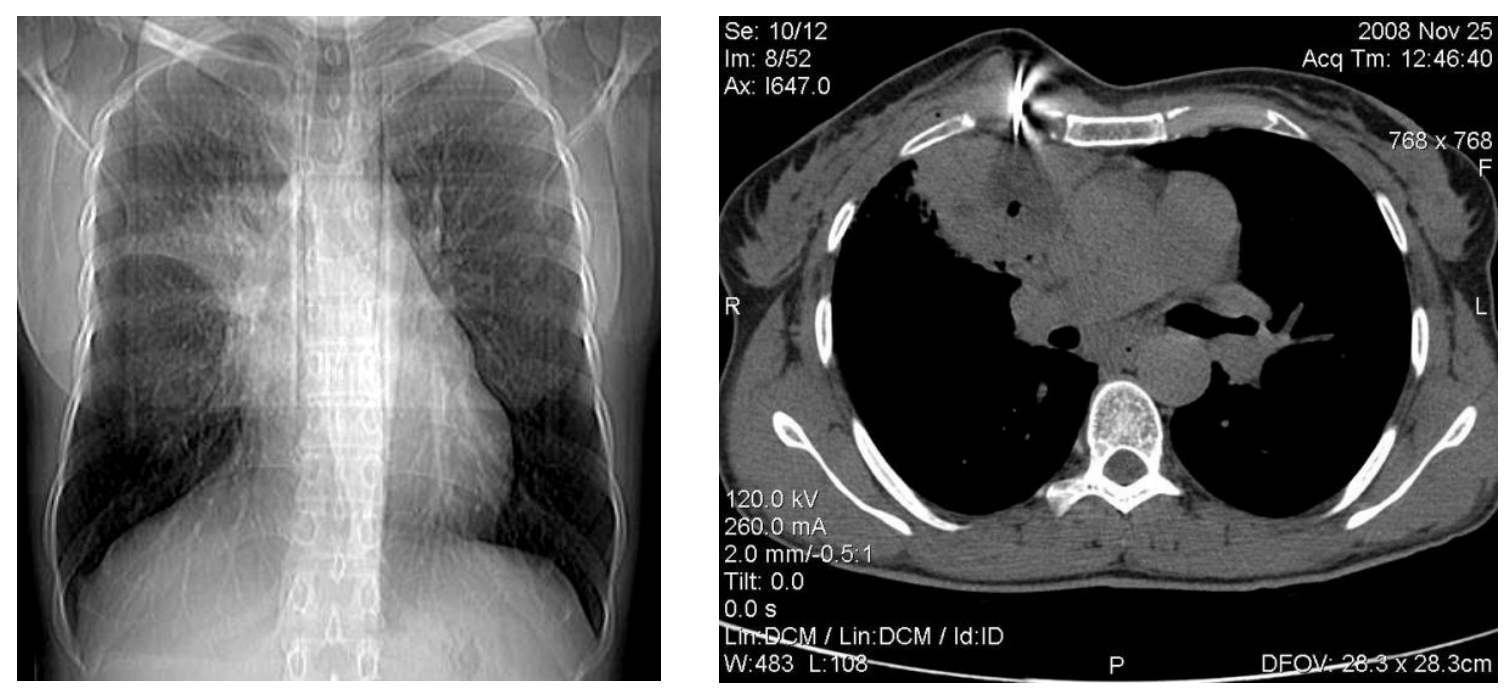

Рис. 1. Пункційна біопсія об’ємного периферичного утвору під контролем КТ ОГК. 
кації обстеження всіх систем (грудна клітка, хребет, черевна порожнина, кістки, голова). Увагу приділяли багаторазовому дослідженню мокротиння на наявність МБТ методами бактеріоскопії (з попереднім збагаченням мокротиння) та висіву на живильне середовище з визначенням чутливості отриманих культур МБТ до основних і резервних протитуберкульозних препаратів.

Проведене операційне лікування 3 патогістологічними дослідженнями підтвердило високу інформативну здатність діагностики СКТ з внутрішньовенним контрастним підсиленням та відеоторакоскопії з біопсією матеріалу, верифікацією поєднаних форм НДРЛ та ТБ.

Критерії включення об’єктів вивчення у дослідження: вік від 40 до 65 років; стать - особи обох статей; клініко-рентгенологічне підтвердження туберкульозних змін у легенях у поєднанні з раком легені у хворих 1-ї та 3-ї клінічних категорій обліку хворих на туберкульоз (ВДТБ - вперше діагностований туберкульоз), 2-ї клінічної категоpiї (ЛПП ТБ - туберкульоз, лікування після перерви; НЛ ТБ - невдача лікування туберкульозу; РТБ - рецидив туберкульозу), 4-ї клінічної категоpiї (Риф ТБ - рифампіцин - стійкий туберкульоз, МРТБ - мультирезистентний туберкульоз та РРТБ - розширено-резистентний туберкульоз); клінічної категорії 5.1 (З3ТБ - залишкові зміни туберкульозу); 1-3А стадія НДРЛ; 0-ІІ ступінь легеневої недостатності. Ефективність віддалених результатів оцінювали на підставі критеріїв клінічного виліковування, прогресування туберкульозу та онкологічного процесу (середня тривалість життя, відсоток місцевих рецидивів пухлинного процесу), формування хронічного туберкульозного процесу, смерті від туберкульозу та раку.

Результати досліджень та ї обговорення. Переважали чоловіки - 81 (89,1 \%), жінок було 10 (10,9 \%). Середній вік в основній групі склав 59 років, у групі порівняння - 61,5 року. У всіх (100 \%) пацієнтів рак поєднувався з активним туберкульозом легень: у 38 відмічено вогнищеву форму у вигляді конгломерату вогнищ, у 20 - залишкові зміни туберкульозу, у 18 - туберкульоми з розпадом, у 8 - фіброзно-кавернозну, у 7 - циротичний туберкульоз. Мікобактерії туберкульозу (МБТ) виділяли у 69,7 \% хворих в основній групі та у 64,6 \% пацієнтів групи порівняння. Центральну форму РЛ виявлено у 12 (31,5 \%) в основній групі та у 19 (35,8 \%) - в групі порівняння, периферичну - у 26 (31,5 \%) та у 34 (64,1 \%) відповідно. При центральній локалізації бронхокарциноми ендоскопічну локалізацію діагностовано в бронхах 1-го, 2-го, 3-го порядку. Пухлини в цій гру- пі хворих ускладнювали бронхіальну прохідність, викликаючи рецидивні пневмонії, параканкрозні пневмоніти, ретростенотичні деструкції. Туберкульоз легень перебігав майже безсимптомно, у фазі ущільнення із появою свіжих вогнищ різної величини та інтенсивності. Фіброзно-кавернозний туберкульоз мав характер стабільного склеротичного процесу. Хворі з периферичним раком легень $(16,5$ \%) спостерігалися з довготривалим стабільним клінічним перебігом (1-2 роки).

У них діагностовано круглий утвір різного діаметра (2-6 см) на фоні пневмосклерозу частки легені. Порушення бронхіальної прохідності при периферичній локалізації раку не спостерігали. Перебіг туберкульозу в таких пацієнтів був більш виражений клінічно: відмічали загострення хронічного ендобронхіту з продуктивно-ексудативною реакцією. При комбінаціях туберкульозу з периферичним раком відмічали часті розпади пухлини за типом асептичного некрозу з утворенням характерних товстих бухтоподібних стінок деструкції. Рак легень із розпадом дуже часто нагадував туберкульозні каверни, але стінки при раку були набагато товстішими із розмитими внутрішніми контурами.

Клінічна симптоматика поєднаних уражень визначалася переважним проявом пухлини та ї̈ ускладнень, а не туберкульозом легень. Симптоматика при центрального раку була вираженішою, ніж при периферичному.

У плані діагностики поєднаних уражень найбільш інформативним виявився рентгенологічний метод. Пухлина частіше локалізувалася в правій легені у 55 (60 \%), ніж у лівій - 36 (40 \%). Локалізація за частками: у верхніх частках - 73 (80,4 \%) випадки (частіше 2 і 3 сегменти), а в нижніх частках - 18 (19,6 \%) (частіше в S 9-10). При активному туберкульозі легень пухлина міститься в тій же легені, частці, сегменті поблизу або в зоні продуктивного туберкульозного запалення (58 \%) (рис. 2, 3). У протилежній легені рак виявлено в $42 \%$ випадків. Порожнисті форми раку легень встановлено у 18,5 \% спостережень. Ателектази частки або сегмента спостерігали у 36,5 \% хворих, а перибронхіальні стенози бронхів - у 30,3 \%.

Фібробронхоскопії проведено в 95 \% хворих із поєднаними ураженнями. Прямі ознаки пухлини виявлено у 11 (11,8 \%) обстежених, непрямі - у 13 (14,2 \%), ендобронхіти специфічного та неспецифічного характеру - у 53 (58 \%) випадках. Лише 11 \% пацієнтів не мали патологічних змін у бронхіальному дереві.

У хворих із підозрою на рак, одиничні вузли в легені при проведенні КТ використовували внутрішньовенне введення контрасту, як показано на рисунках 4, 5. 

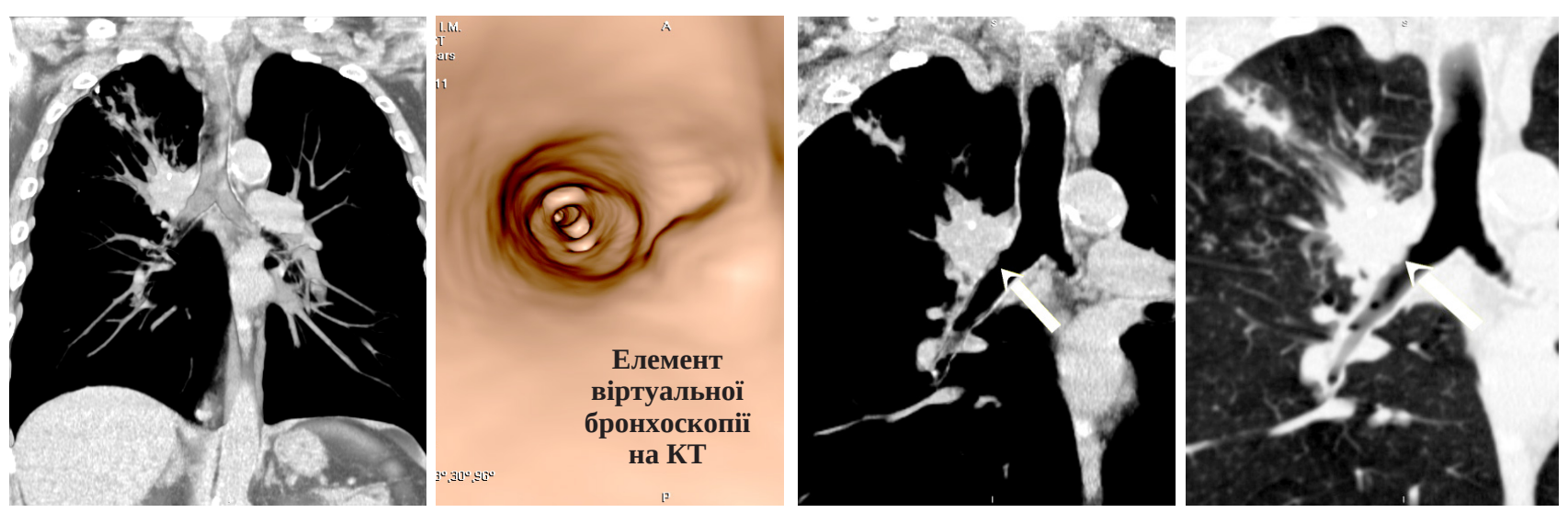

Рис. 2. Хворий Д. Центральний с-r верхньої частки справа. Залишкові зміни після перенесеного туберкульозу.
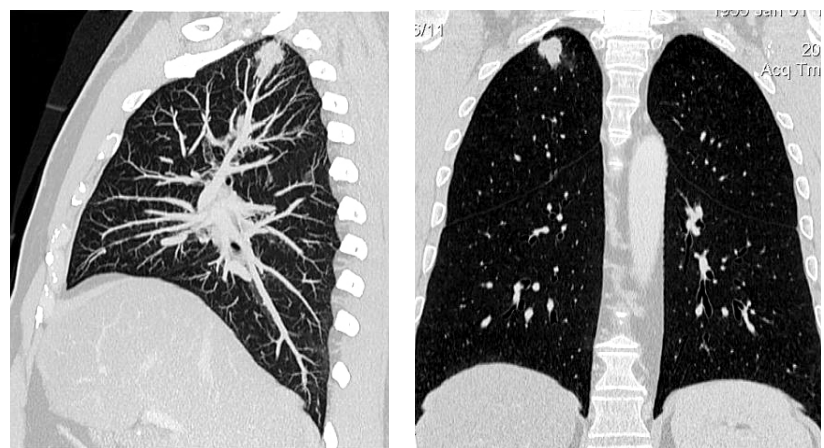

Рис. 3. Хворий Д. Периферичний с-г верхньої частки справа. Залишкові зміни після перенесеного туберкульозу. Сагітальна МІР та коронарна реконструкції.
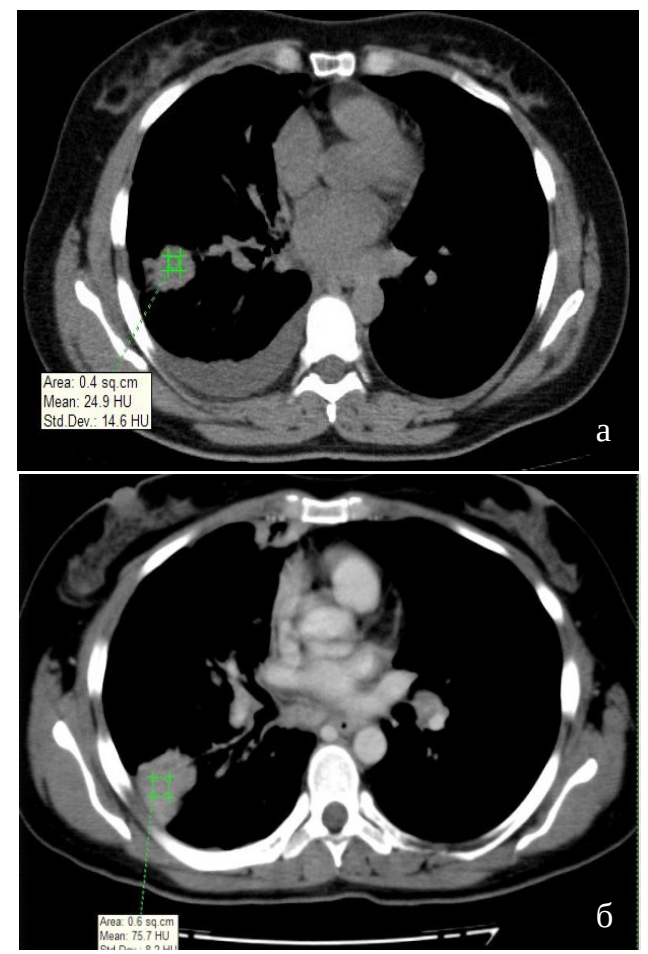

Рис. 4. Периферична пухлина: а - хвора Г. (КТ ОГК нативно). Кругла тінь нижньої частки правої легені, щільність +25 од Н, плеврит, до +75 од Н; б - КТ через 3 тижні з внутрішньовенним підсиленням. Вузол контрастно підсилився та значно збільшився в розмірах.

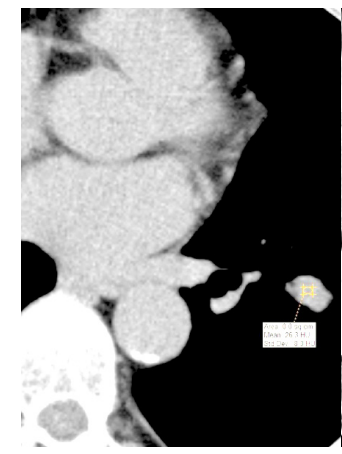

a

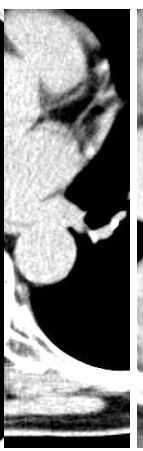

б
Рис.5. Туберкульома: а - КТ ОГК нативно; вузол нижньої частки лівої легені +26 од Н, кальцинат в корені; б - КТ ОГК після внутрішньовенного контрастування. Вузол нижньої частки лівої легені не підсилився +23 од $\mathrm{H}$.

Цитологічно у мокротинні у 41,3 \% пацієнтів виявлено ракові клітини, в 67,1 \% - сліди крові, у 48,8 \% - метаплазію епітелію бронхів різного степеня зрілості (передвісники раку в мокротинні). Браш-біопсія 3 наступним бронхіоло-альвеолярним лаважем із підозрілих на РЛ бронхів у 58 \% показала злоякісний процес. Гістологічний аналіз операційного матеріалу в 91 хворого показав, що злоякісна пухлина формувалася з фіброзною капсулою туберкульоми в ділянці поділу субсегментарного, сегментарного чи часткового бронхів. Гістологічно встановлено, що туберкульозна гранульома (рис. 6) викликає некроз елементів бронхіального дерева та строми легеневої паренхіми. Це, в свою чергу, призводить до облітерації судин середнього та великого калібру та потовщення міжальвеолярних перегородок, в зоні яких і виявлено пухлинне переродження (рис. 7).

При поєднаній патології в 64 (69,3 \%) випадках гістологічно підтверджено аденокарциному, в 24 (27,1 \%) - плоскоклітинний рак, в 2 (5,3 \%) - бронхіолоальвеолярний, а в 1 (1,9 \%) - недиференційований рак легень. Отже, методики ранньої діагностики бронхолегеневого раку слід шукати в 


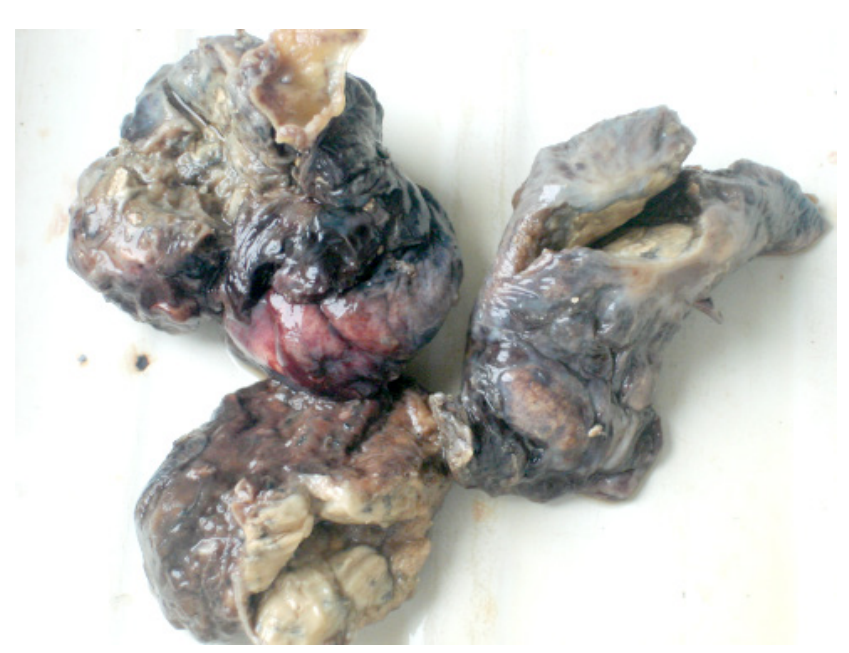

Рис. 6. Гістологічний препарат. Хворий Ж. Залишкові зміни туберкульозу, туберкульоми.

проблемах операційної фтизіохірургії сьогодення: активні туберкульозні зміни в легеневій тканині, бацилярність хворого не є протипоказаннями до операційного лікування з приводу РЛ.

Висновки. 1. У діагностиці поєднаних уражень туберкульозу і раку легень сучасні рентгенологічні обстеження, зокрема комп'ютерне томографічне обстеження грудної клітки з внутрішньовенним контрастним підсиленням, фібробронхоскопія 3

\section{СПИСОК ЛІТЕРАТУРИ}

1. Тюрин И. Е. Компьютерная томография органов грудной полости / И. Е. Тюрин. - СПб., 2003. - С. 15-60.

2. Перельман М. И. Рак легкого / М. И. Перельман // Пробл. туберкулеза и болезней легких. - 2005. - № 6. - С. 10-20.

3. Фещенко Ю. І. Стан надання фтизіатричної допомоги населенню України / Ю. І. Фещенко // Укр. пульмон. журн. 2008. - № 3 (додаток). - С. 809-814.

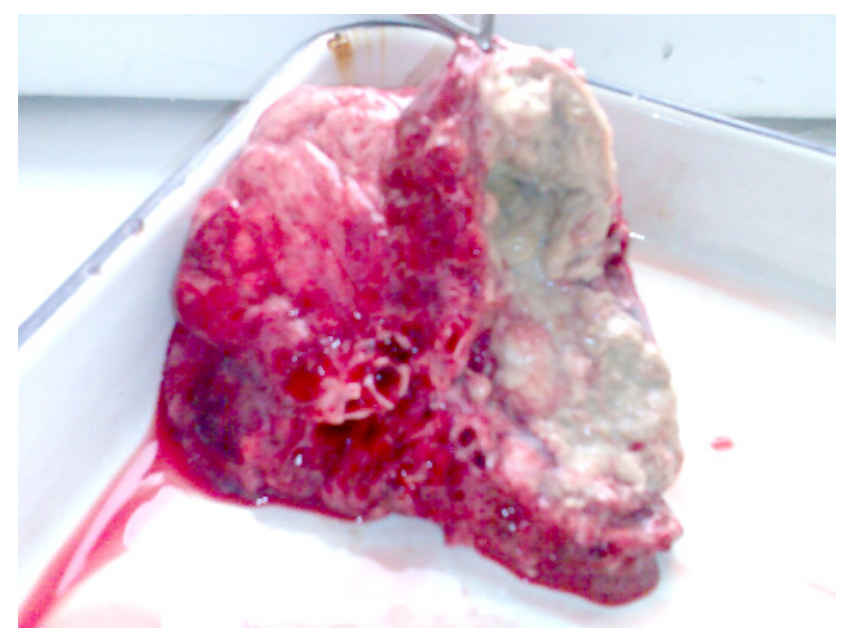

Рис. 7. Гістологічний препарат. Хворий Д. Фіброзно-кавернозний + c-r верхньої частки справа + множинні туберкульоми з розпадом.

цитологічним та гістологічним дослідженнями мають першочергове значення для своєчасної діагностики.

2. Неопластичні трансформації виникають у легенях, патологічно змінених туберкульозом чи повторними неспецифічними запаленнями в сегментах. А тому слід відмовитись від довготривалого динамічного спостереження за пацієнтами із великими залишковими змінами в легенях при підозрі на рак легень.

4. Ashizawa K. Coexistence of lung cancer and tuberculoma in the same lesion:demonstration by high resolution and contrast-enhanced dynamic CT/ K. Ashizawa // British Journal of Radiology. - 2004. - Vol. 77. - P. 959-962.

5. Collins J. CT signs and patterns of lung disease / J. Collins // Radiol. Clin. North Am. - 2001. - Vol. 39, № 6. - P. 11151135.

Отримано 01.11.16 